\title{
Pelatihan Internet Marketing (Facebook ADS) Wirausaha Muda Di Rumbai
}

\author{
AZNURIYANDI $^{1}$, ADI RAHMAT $^{2}$, DWIKA LODIA PUTRI $^{3}$ \\ 1,2,3 Universitas Lancang Kuning \\ Jln. Yos Sudarso KM 08 Rumbai Telp. (0761) 52581 \\ E-mail : Aznuriyandi@unilak.ac.id
}

\begin{abstract}
Community Service activities are intended to provide training in developing their skills so that they have the ability to use internet marketing (Facebook advertising) and are able to grow entrepreneurial spirit and to find out young entrepreneurs towards internet marketing training (facebook ads) as well as fostering entrepreneurial spirit. The method of community service activities uses the lecture method, demonstrations directly practiced by participants, and question and answer. The lecture method is used to convey general knowledge about internet marketing (facebook ads). Demonstrations are used to provide direct training regarding the process of making good advertising and determining the desired target market, the equipment needed and the materials used in this Internet marketing training, Computer or Mobile and internet. Question and answer is used to supplement things that have not been accommodated by the method above. This training involved lecturers from the Accounting and Management Department who worked with young entrepreneurs in Pekanbaru Tassel as the target.
\end{abstract}

Keywords: Internet Marketing, Community Service, Young Entrepreneurs

Dalam menghadapi perkembangan zaman saat ini, arus globalisasi teknologi dalam menghadapi persaingan bisnis. Persaingan ketat dalam memasarkan produk menciptakan berbagai teknologi pemasaran. Banyak perusahaan yang berinovasi dari pemasaran biasa menjadi berbasis teknologi (Internet Marketing).

Facebook saat ini salah salah satu media sosial yang terbesar pemakaiannya di indonesia makanya penjualan melalui facebook ini sangat pontensial. Seiring perkembangan zaman kita dapat melihat banyak peralihan didalam dunia bisnis dimana para pengusaha dan pedagang telah banyak beralih ke media sosial. Banyak media sosial yang telah membuat para pengusaha dan pedagang dapat meningkatkan omset nya melalui media sosial. Facebook awalnya hanya digunakan untuk media sosial sekarang terus tumbuh dan berkembang menjadi tempat para pengusaha dan pedagang dalam memasarkan produk atau lainnya. Sekarang dapat kita kenal produk dari facebook ini yaitu facebook Ads. Facebook Ads ini salah satu sistem pemasaran melalui media internet yang bisa menjangkau puluhan ribu pengguna facebook tanpa harus berteman. Banyak pengusaha yang telah memanfaatkan berjualan dan memasarkan produk atau untuk mengkampanyekan berbagai macam bentuk dan jenis produk.

Untuk sebagai bekal bagi wirausahawan muda agar dapat berkompetisi baik di dalam negeri maupun di luar negeri dalam menjalankan usahanya. Adapun yang tergabung dalam wirausahaan muda ini meliputi pedagang kecil dan mahasiswa. Bekal yang diberikan yaitu pengetahuan tentang berwirausaha dan internet marketing. Berwirausaha ini memiliki banyak keuntungan yang dapat memotivasi seseorang untuk melakukan wirausaha, yakni dengan berwirausaha seseorang dapat mengatur dan merencanakan usahanya sendiri sesuai dengan tujuan yang ingin dicapai, jika memilih berwirausaha maka kita dapat menjadi pimpinan atau bosbagi usaha sendiri. 
Peran dari seorang wirausaha secara umum memiliki 2 peran, yaitu: sebagai penemu dan sebagai perencana. Sebagai penemu, wirausaha menemukan dan menciptakan produk baru, teknologi dancara baru,ide-ide baru dan organisasi usaha baru. Sedangkan sebagai perencana, wirausaha berperan merancang usaha baru, merencanakan strategi perusahaan baru, merencanakan ide-ide dan peluang dalam perusahaan. Selain bekal wirausaha ini, perlu adanya bekal dalam menghadapi pesaing, maka perlu juga belajar internet marketing, internet marketing adalah sarana untuk membantu dalam memperkenalkan produk dengan cepat dan bisa menjangkau lebih luas lagi dan dapat meningkatkan omset.

Diharapkan para wirausahaan muda ini mempunyai skill internet marketing, skill ini salah satu bentuk keunggulan yang harus dimiliki dalam memasarkan produk. Permasalahan yang dihadapi di para wirausahaan muda di wilayah rumbai adalah sebagai berikut : Belum adanya pelatihan dan sosialisasi tentang penggunaan internet marketing menggunakan facebook ads. Kurangnya pemahaman tentang pemasaran menggunakan sistem internet marketing, sehingga tidak tahu bagaimana memulai bisnis atau mengembangkan bisnisnya, sedangkan penerapan sistem internet marketing (facebook ads) ini belum diperoleh.

Masih kurangnya motivasi bisnis untuk pengembangan usaha. Hal ini berakibat kegiatan usaha berjalan secara stagnan tanpa ada upaya untuk pengembangan skala usaha yang lebih besar.

\section{METODE}

Metode yang akan dilakukan oleh tim selama kegiatan pengabdian bagi masyarakat dengan Mitra wirausaha muda di rumbai.

a. Metode Ceramah

Dengan cara melakukan motivasi dengan menjelaskan langsung kepada mitra dengan tujuan untuk membangkitkan gairah jiwa bisnis/kewirausahaan.

\section{b. Metode Praktek}

Dengan cara melakukan praktek secara langsung sesuai dengan materi yang akan disampaikan kepada mitra. Melalui kegiatan praktek langsung diharapkan mitra mendapatkan pengetahuan tentang cara membuat sistem pemasaran menggunakan Facebook Ads, sehingga menambah kegunaan dari produk tersebut.

\section{c. Enterpreneurship Motivation}

Pada kegiatan ini akan dilakukan pemberian motivasi pentingnya kewirausahaan. Kegiatan ini dilakukan dalam bentuk pelatihan menggunakan aplikasi facebook ads serta memberikan motivasi jiwa wirausaha dalam bentuk tukar pengalaman dengan usahawan lainnya. Kegiatan ini diarahkan untuk membangun mindset jiwa wirausaha bagi mitra usaha sehingga dapat menimbulkan motivasi jiwa wirausaha dan pengembangan usaha mitra. Kegiatan ini dilakukan dalam bentuk diskusi interaktif untuk mengungkap permasalahan dan potensi usaha yang dapat dikembangkan oleh mitra.

Adapun rencana kerja yang akan dilakukan dalam program ini adalah:

1. Menghubungi Mitra wirausaha muda Rumbai.

2. Menghubungi Mitra wirausaha muda Rumbai yang ada dalam kegiatan ini

3. Memberikan pelatihan untuk meningkatkan ketrampilan bagi mitra .

Prosedur kerja yang akan dilakukan adalah:

1. Memberikan motivasi bagi semua peserta agar dapat memasarkan produk dengan menggunakan aplikasi Facebook ads.

2. Memberikan pelatihan bagaimana cara membuat dan menggunakan aplikasi Facebook ads.

3. Memberikan penyuluhan dan pelatihan dengan menggunakan Facebook ads dapat meningkatkan penjualan, sehingga dapat meningkatkan omset. 
4. Memberikan pelatihan bagaimana memasarkan produk melalui internet.

5. Memberikan penyuluhan bagaimana strategi pemasaran untuk produk yang dihasilkan.

Dalam hal ini partisipasi mitra sangat diharapkan agar program ini dapat terlaksana yaitu dengan cara menunjukkan kesediaan mitra wirausaha muda untuk ikut dalam kegiatan ini yang diperkuat dengan surat kesediaan mitra untuk berpartisipasi.

\section{HASIL}

Kegiatan penyuluhan dalam rangka meningkatkan pengetahuan dan pemahaman tentang Internet Marketing (Facebook Ads) wirausaha muda dirumbai Kota pekanbaru Provinsi Riau, dilakukan di salah satu tempat usaha warga di Rumbai Pesisir yang dihadiri oleh Wirausaha Muda Rumbai.

Pelaksanaan kegiatan ini setelah dilakukan beberapa kali koordinasi dengan pihak Wirausaha Muda Rumbai tentang peserta pelatihan di wilayah Rumbai yang menjadi target penyuluhan, waktu pelaksanaan PKM serta tempat yang layak sebagaimana tertuang dalam dokumen rencana kegiatan.

Kegiatan penyuluhan tentang Pelatihan Internet Marketing (Facebook Ads) Wirausaha Muda Di Rumbai dilakukan dengan pola penyampaian materi. Kegiatan pelaksanaannya dilakukan pada tanggal 22 Desember 2018 dalam rentang waktu pukul 09.00 sampai dengan pukul 12.30 WIB.

Acara dibuka oleh salah satu Wirausaha Muda yang ada di Rumbai, anggota tim pelaksana kegiatan terlebih dahulu memberikan materi penyuluhan kepada peserta yang hadir. Pemberian materi kepada peserta ini dimaksud agar peserta lebih mudah mengetahui dan memahami materi sehingga diharapkan dapat menjadi pedoman bagi peserta untuk mengajukan pertanyaan maupun diskusi yang proaktif pada saat penyuluhan berlangsung. Setelah peserta hadir, acara penyuluhan dibuka dan dilanjutkan dengan kegiatan penyampaian materi-materi penyuluhan oleh seluruh tim pelaksana kegiatan secara bergantian.
Evaluasi pada tahap pertama sesuai dengan indikator dan rancangan evaluasi diperoleh data sebagai berikut:

1. Jumlah peserta yang hadir sebanyak 30 orang dari 40 peserta yang diharapkan hadir sehingga hampir $100 \%$.

2. Keantusiasan peserta sangat terlihat jelas dimana hampir seluruh peserta aktif terlibat dalam proses kegiatan hingga selesai.

Evaluasi pada tingkat kesukaan konsumen (peserta) hampir semua peserta $>95 \%$ menyatakan suka dengan hasil kegiatan.

\section{PEMBAHASAN}

Materi penyuluhan tentang Pelatihan Internet Marketing (Facebook Ads) Wirausaha Muda di Rumbai ini disampaikan oleh para narasumber. Penyampaian materi oleh narasumber dilakukan dengan sistem diskusi. Setelah seluruh materi disampaikan, dilanjutkan dengan diskusi terbuka dan berbagi pengalaman dengan para peserta. Penyampaian materi dilakukan dengan bahasa yang mudah dipahami. Untuk kelancaran, kenyamanan dan ketertiban penyelenggaraan penyuluhan, praktek maupun diskusi yang berlangsung, maka strategi yang dilakukan adalah dengan melakukan dialog interaktif pada setiap materi yang disampaikan.

Tahap pengamatan secara mendalam dan komprehensif (monitoring) dan evaluasi pelaksanaan kegiatan penyuluhan terhadap para peserta merupakan tolok ukur untuk mengetahui capaian atau terdapatnya peningkatan pengetahuan, pemahaman dan perilaku (kompetensi) peserta.

Kegiatan monitoring partisipasi peserta dilihat sejak dimulainya sosialisasi penyuluhan sampai pada penutupan penyuluhan. Dalam tahap ini, setiap materi yang disampaikan oleh narasumber atau fasilitator, seluruh peserta merespon aktif dengan perhatian yang optimal. Begitu pula pada alokasi waktu untuk diskusi, keaktifan para peserta juga dimonitoring, yang mana 
sebagian besar peserta sangat aktif mengajukan pertanyaan bahkan berulangulang sesuai dengan masalah yang dihadapinya dalam keluarga, dan cukup relevan dengan materi yang disampaikan atau masih terkait dengan kesulitan dalam menyelesaikan masalah perencanaan keuangan peserta. Berbagai pertanyaan yang diajukan peserta, narasumber berupaya memberikan jawaban dengan memberikan contoh dalam mengatasi setiap masalah yang sudah dialami dan sedang dihadapi dengan menggunakan bahasa yang mudah dipahami oleh peserta.

Hasil yang diperoleh dari penyebaran kuesioner ke peserta kegiatan sebanyak 30 orang, sebelum dan sesudah kegiatan dilaksanakan adalah sebagai berikut:

Tabel 1: Tingkat Pengetahuan Peserta Sebelum dan Sesudah Pelaksanaan PKM

\begin{tabular}{|c|c|c|c|c|c|}
\hline \multirow[b]{2}{*}{ No } & \multirow[b]{2}{*}{ Pertanyaan } & \multicolumn{2}{|c|}{ Sebelum } & \multicolumn{2}{|c|}{ Sesudah } \\
\hline & & Ya & Tidak & Ya & Tidak \\
\hline 1 & $\begin{array}{l}\text { Sebelum penyuluhan ini anda } \\
\text { sudah mengetahui tentang internet } \\
\text { marketing dalam menjalankan } \\
\text { usaha anda }\end{array}$ & 22 & 8 & 30 & 0 \\
\hline 2 & $\begin{array}{l}\text { Sebelum penyuluhan ini anda } \\
\text { sudah mempunyai keterampilan } \\
\text { mengenai aplikasi internet } \\
\text { marketing }\end{array}$ & 15 & 15 & 30 & 0 \\
\hline 3 & $\begin{array}{lr}\text { Untuk mempercepat kemampuan } \\
\text { proses pemasaran r anda } \\
\text { membutuhkan aplikasi internet } \\
\text { marketing }\end{array}$ & 10 & 20 & 30 & 0 \\
\hline 4 & $\begin{array}{l}\text { Pengetahuan yang minim tentang } \\
\text { program aplikasi internet } \\
\text { marketing akan mempengaruhi } \\
\text { perkembangan usaha }\end{array}$ & 6 & 24 & 30 & 0 \\
\hline 5 & $\begin{array}{l}\text { Kegiatan penyuluhan ini sangat } \\
\text { bermanfaat untuk membantu } \\
\text { pengembangan usaha anda }\end{array}$ & 20 & 10 & 30 & 0 \\
\hline 6 & $\begin{array}{l}\text { Waktu diskusi untuk penyampaian } \\
\text { masalah-masalah yang dihadapi } \\
\text { peserta dalam pemasaran hasil } \\
\text { usahanya cukup memadai }\end{array}$ & 30 & 0 & 15 & 15 \\
\hline 7 & $\begin{array}{l}\text { Perlu adanya pelatihan dan } \\
\text { penyuluhan yang lebih intensif } \\
\text { untuk meningkatkan pengetahuan } \\
\text { dan informasi yang lebih optimal } \\
\text { dalam menggunakan aplikasi } \\
\text { internet marketing. }\end{array}$ & 30 & 0 & 30 & 0 \\
\hline
\end{tabular}

Sumber: Hasil Olah Data Kuesioner

Sebagian besar dari peserta sangat tertarik mengajukan pertanyaan seputar kesulitan dalam menjalankan aplikasi internet marketing dalam menjalankan usahanya saat ini. Selanjutnya, penyelenggaraan penyuluhan tentang Pelatihan internet Marketing (Facebook Ads)
Wirausaha Muda di Rumbai, dievaluasi oleh peserta atas kinerja prosesi pelaksanaan penyuluhan ini.

Berdasarkan tabel diatas terlihat sebenarnya peserta sudah mengetahui bagaimana menggunakan Aplikasi Internet Marketing (Facebook Ads). Akan tetapi kemampuan teknis seperti bagaimana starategi pemasaran yang bagus memang belum dimiliki oleh para peserta PKM.

Setelah mendapat penyuluhan terlihat pengetahuan para peserta meningkat. Dari tabel diatas terlihat bahwa peserta sudah mengetahui bagaimana menggunakan Aplikasi Internet Marketing (Facebook Ads) untuk memasarkan hasil usaha mereka.

Secara keseluruhan pelaksanaan PKM cukup berhasil karena peserta mampu menguasai materi, baik dari aspek manajemen maupun menggunakan Aplikasi Internet Marketing lebih dari $70 \%$ sesuai yang ditargetkan.

Dengan diadakan sosialisasi dan penyuluhan tentang Pelatihan Internet Marketing (Facebook Ads) Wiruasaha Muda di Rumbai memperoleh hasil dan manfaat, terutama bagi Wirausaha Muda di Rumbai. Tim mampu memberikan pengetahuan baru untuk pelaku usaha sektor UMKM. Terjalin kerjasama antara pihak Wirausaha Muda di Rumbai dan dosen pelaksana program pengabdian kepada masyarakat khususnya dan Universitas Lancang Kuning pada umumnya. Dosen mampu melaksanakan tri dharma perguruan tinggi yaitu pengabdian kepada masyarakat dengan terlaksananya kegiatan ini.

Hasil pengabdian ini sejalan dengan apa yang disampaikan oleh Fatkhurahman, F. (2018) bahwa butuh penerapan teknologi dalam berwirausaha sehingga produk yang dihasilkan memiliki daya saing.

\section{SIMPULAN}

Dari hasil kegiatan penyuluhan mengenai tentang Pelatihan Internet Marketing (Facebook Ads) Wirusaha Muda ini dapat disimpulkan sebagai berikut: 
Pengetahuan Wirausaha Muda pelaku-pelaku usaha khususnya tentang penggunaan Aplikasi Internet Marketing sebagai syarat untuk tumbuh kembang usahanya, secara umum meningkat. Untuk menggerakkan UMKM di Rumbai, kedepan diperlukan perlu dilakukan pelatihan aplikasi ini secara kontinu dalam memberikan ilmu-ilmu baru dalam pengembangan dari aplikasi Internet Marketing ini.

Berdasarkan kesimpulan diatas dapat dibuat beberapa saran, yaitu: Perlu adanya penyuluhan yang lebih intensif untuk meningkatkan pengetahuan dan informasi yang lebih optimal mengenai Aplikasi Internet Marketing (facebook Ads) Wirausaha Muda di Rumbai.

Alokasi waktu penyelenggaraan perlu ditambah terutama untuk sesi diskusi agar lebih banyak waktu menyampaikan beberapa masalah-masalah yang dihadapi pelakupelaku usaha UMKM, khususnya pelaku usaha mikro dan kecil.

\section{DAFTAR RUJUKAN}

Barthos, Basir. 1999, Manajemen Sumber Daya Manusia, cetakan keenam, Penerbit Bumi Aksara, Jakarta.

Buchari Alma. 2003. Bandung: Alfabeta. Kewirausahaan.

Fatkhurahman, F. (2018). Pengaruh Faktor Diri Sendiri, Faktor Keluarga, Faktor Masyarakat Dan Metode Belajar Terhadap Pengembangan Jiwa Kewirausahaan Mahasiswa. In Prosiding Seminar Nasional Teknopreneur Universitas Pasir Pengaraian (Vol. 1, No. 1, pp. 222228).

Suryana, 2006. Kewirausaan Pedoman Praktis: Kiat, dan Proses Menuju Sukses. Jakarta. Penerbit Salemba.

Widyanigrum, premi wahyu, bharata, wira. 2017. Workshop internet dan digital marketing untuk meningkatkan daya saing pada kelompok pengusaha muda Ponorogo. Jurnal pengabdian kepada masyarakat ADIMAS. Vol 1. No. 1. Maret tahun 2017

Zimmerer, W. Thomas, Norman M. Scarborough. 1996. Entrepreneurship and The New Venture Formation. New Jersey: Prentice Hall International Inc. Hal. 3, 5, 6, 7, 51, 52, 53. 